\title{
The Changing Role of Ministers in the Legislative Agenda in Brazil
}

\author{
Lúcio Rennó* | Universidade de Brasília \\ Stefan Wojcik** | Northeastern University/Harvard IQSS
}

\begin{abstract}
Who, within the Cabinet, participates in elaborating the government's legislative agenda, and why? How has the role of ministers in elaborating the legislative agenda changed over time? In this paper, we discuss the structure of legislative bill cosponsorship networks among cabinet members in Brazil. Are ministers serious participants in the elaboration of the agenda, sharing its authorship with colleagues from their and other parties in the coalition? We develop a theory of cabinet members' participation in the formulation of the government's legislative agenda in the Brazilian Congress. Using descriptive statistics and network-analytic techniques, we reveal continuity and change in the role of ministers in the legislative agenda over time.
\end{abstract}

\section{What is Cabinet Cosponsorship?}

This paper is about how ministers participate in the formulation of the government's legislative agenda in multiparty presidential systems. There are several mechanisms through which this can occur. First, ministers can prepare the content of the bill individually, becoming single authors of the proposition. Second, they can author the bill in direct collaboration with other cabinet members, through continuous and iterative meetings, phone calls, emails between the staffs of two or more ministries. Third, ministers can revise and edit the content of a bill designed by another minister. This would cause a bill to be sent back to the original minister for further reactions, spurring collaboration between them. Fourth, a minister could simply accept the content of the bill designed by another minister and ratify it, but this at least requires some evaluation of the bill's content and legal standing.

Except for the fist case above, all of these processes entail continuous communication and interaction among ministries and exchange of ideas in reaching a consensus about the content of the legislative proposal. In particular, we are interested in processes of collaboration between ministers in authoring the government's legislative agenda, with an emphasis on cross-partisan collaboration. In this respect, we examine how coalitions work within the executive branch in formulating the government's legislative agenda.

When a minister signs a bill or it's exposition of motives, this is an indication that the minister at least has been consulted and reviewed the decision-making process and content of the bill'1. In the minimum, a formal legal procedure is started within the ministry and a legal evaluation elaborated. Usually, however, endorsing a bill means much more than that. It indicates investing time and human resources in drafting, editing or revising a proposition. In fact, as we contend later, the cosponsorship of a bill represents an intense and long process of negotiation and exchange of ideas between ministries' staffs, with the coordination, more often than not, of the 
president's staff. Hence, coauthorship is a strong indicator of relationships among cabinet members, and not merely a formality.

Despite the apparently important role that ministers play in proposing legislation, the literature on presidential systems, coalitions and executive/ legislative relations has barely paid attention to how bills are formulated in the executive branch and who participates in this process. We know very little, if anything at all, about the impact and relationship between ministers in formulating policy proposals. Policy preference congruence among the coalition is only rarely considered as a factor influencing the functioning of the coalition (Figueiredo and Limongi, 2008; 2009). In fact, we know nothing about policy construction within the government in coalitional presidentialism. Once the coalition is formed, who participates in drafting the government's legislative agenda? Do cabinet members in different ministries and from different parties collaborate in constructing a joint, shared government agenda? Does cabinet composition affect cooperation among cabinet members on authoring legislative initiatives? What accounts for variation in cooperation across time?

We explore these issues focusing on the case of Brazil, a least likely case for the occurrence of coauthorship. In principal, presidents in Brazil do not need to spend much effort in stimulating the collaboration of coalition members because the constitution concentrates power in the presidency, granting it many tools to negotiate directly with parties and representatives in Congress (Raile et al., 2011; Martinez-Gallardo, 2012). As a consequence, Brazil is a case of extreme cabinet instability in Latin America (Martinez-Gallardo, 2012). If we find collaboration and coauthorship in this least-likely case, it is possible that this phenomenon is recurrent in other multiparty presidential systems based on coalition government throughout Latin America. At least it will indicate the need to more closely address who participates in constructing the government's legislative agenda in a comparative perspective.

Ministers are connected to each other through their cosponsorship of legislative proposals. We use network analysis to map the contours of the interactions among ministers based on their cosponsorship of legislation. Such mapping reveals the interpenetration of ministerial agendas, or the degree to which coauthorship on policy proposals is dispersed across a wide array of cabinet posts.

We focus on four characteristics of cosponsorship - the intensity of cosponsorship for individual ministers (network centrality), intensity of linkages among stakeholders (network density), working closely with one another (social proximity), and the repetition of working relationships (relationship repetition). As a consequence, we propose measures based on network analysis of the density of associations among ministers, their social distance, and how consistently cooperative the coalition is. We find that cooperation among cabinet members in policy-making is more common than one would expect, that it varies only mildly according to the characteristics of the cabinet and that most of the government's agenda is drafted in the ministries, not in the executive center of power or its imaginary equivalent (even though the extent of this participation can vary cross-nationally). Finally, parties other than the president's also appear as important collaborators in constructing the agenda when there is coauthorship.

This paper proceeds in four further parts. In the next section, we lay out our interpretation of the literature concerning cabinet formation and bargaining. In the second section, we discuss our theory of coalitional cooperation and role specialization among ministers. In the third section, we propose and defend our hypotheses. In the fourth section, we present our empirical results and conclude.

\section{Literature Review: Conventional Wisdom}

Much is known about the functioning of governing coalitions within the legislature and the delineation of executive/legislative relations, especially in Latin America, and Brazil in particular (Figueiredo and Limongi, 1999; Ames, 2001; Amorim Neto, Cox and McCubbins, 2003; Pereira, Power and Renno, 2005; 2007; Pereira and Mueller, 2002; Negretto, 2004; Aleman and Saiegh, 2007; Saiegh, 2010; Raile, Pereira and Power, 2011). Analysts regard pork and patronage as a central means of coalition management (Amorim Neto, Cox and McCubbins, 2003; Pereira, Power and Renno, 2005; Raile, Pereira and Power, 2011). We know that the distribution of cabinet portfolios to coalition members is essential for the construction and consolidation of the governing coalition (Amorim Neto, 2002; 2006). Furthermore, the literature has also made progress in assessing the formation, duration and termination of cabinets (Martinez-Gallardo, 2012; Amorim Neto, 2002; 2006; Chasquetti et al., 2013; Inacio, 2013; Dávila et al., 2013; Carreras, 2013; Camerlo, 2013). However, we know nothing about how the government coalition in the executive branch actually constructs, on a day-to-day basis, its policy agenda that is later submitted to legislative review. We know very little about the role that ministers play in this process.

We do know that coalition bargaining varies across institutional arrangements. Parliamentary and presidential systems induce different coalitional outcomes, owing to the different timing and strategy involved in bargaining under each institutional arrangement. The institutional differences between multiparty presidential systems and other systems are known to lead to different incentives to participate in government (Strom, 1990; Mainwaring, 1993; Cheibub and Limongi 2002). The nature of the mandate also plays a part as well - legislatures that are highly fragmented, ideologically diverse, and lacking 
a clear majority make coalition bargains more complicated. Coalitional bargains are the logical first step in analyzing why and when cooperation among coalition partners occurs, and we believe there is much to learn by looking at this topic comparatively.

In parliamentary systems, ministers are key policymakers (Laver and Shepsle, 1994; 1996; Thies, 2001; Martin and Vanberg, 2004; Dewan and Myatt, 2007). In such systems, unified executive-legislative relations render majority governments highly likely. A government formateur makes policy concessions by granting cabinet positions to parties until a majority is reached. Once a government has been formed, policy proposals reflect a bargain among parties comprising the government coalition, expressed in the coalition agreement, which is binding in some countries (Laver and Shepsle, 1994). Incorporating cabinet members in authoring the government's legislative agenda is a form of distributing influence across coalition members, of potentially increasing the likelihood of approval in congress and a response to ever increasing transversal demands.

In presidential systems, ministers sometimes play similar roles as in parliamentary systems. By focusing exclusively on the period of government formation, Negretto (2006) shows that presidents can build cooperation between branches of government by doling out cabinet positions such that a majority of parties are represented in government. It is assumed that such cooperation leads to substantive policy outcomes of a similar nature - bounded in time but reflecting the characteristics relevant at the time of cabinet formation. The initial choice of cabinet constitution conditions the entire functioning of the future government. Most of the current studies on the cabinet espouse a similar view. Government formation, a strategic choice of presidents, conditions policymaking (Amorim Neto, 2002; Martinez-Gallardo, 2012).

A multiparty presidential system does not always produce majority cabinet coalitions so readily, and much less so have clear-cut coalition agreements that set the government's policy goals in comparison to some parliamentary systems. Nonetheless, choices over which parties to include in the cabinet coalition are assumed to affect policymaking - cabinet choices reflect bargains made between the president and parties in congress. In spite of the lack of a coalition agreement, all policymaking is contingent upon standing committees, specialization, scope, and allocation rules (Cheibub and Limongi, 2002). This view offers the compelling argument that institutional forces will tend to dominate the drafting of policy.

Building coalitions in multiparty systems is costly, even when controlling for levels of ideological heterogeneity. Building cabinet cosponsorship with broad inclusion is difficult. Amorim Neto (2006) has shown that usually more than four or five parties comprise the cabinet with varied and, one would think, irreconcilable ideological positions. It does not seem likely that cabinet members of diverse parties would set aside ideological differences and cooperate (or at the very least, such cooperation should be heavily constrained). Of course, there are practical reasons why coauthorship is harder: it requires coordination and negotiation, which are difficult to achieve, time consuming and, therefore, more costly than when one works alone. Hence, the expectation is that cooperation should be rare.

Concern with the composition of the coalition is even lower when the executive branch has a broad range of legislative prerogatives (Martinez-Gallardo, 2012). Presidents frequently use decree power to set policy unilaterally (albeit conditional on the patterns of executive/legislative relations (Pereira, Power and Renno, 2005)), creating a disincentive for cabinet cooperation (Martinez-Gallardo, 2012). More interestingly, presidents do not need the support of coalitions to continue governing. In fact, when minority presidents have a majority of legislative support, they are less likely to build coalitions at all (Negretto, 2006).

The use of pork and patronage is also an important determinant of coalition bargaining. The strategic decision-making of the president and his or her institutionally-derived policy tools influence the costs of including other stakeholders, the content of policy, and the likelihood of policy success (Martinez-Gallardo, 2012). Of particular interest is the use of the budget. The ability of the president to control the funding of ministries through extraordinary budgetary credits and other important institutionally-derived policy tools subordinates ministers to the will of the president. Given that the president can fund or de-fund particular ministries, cooperation among cabinet ministers ebbs and flows with the use of budgetary measures. Therefore, the institutionally-derived dominance of the president over the trajectories of legislative proposals and the ability to dole out incentives implies that cosponsorship begins and ends with the demands of the president.

There is a generalized idea that presidents draft the government's agenda with the assistance of their close aides, behind closed doors, and impose this agenda on the coalition. Coalition members, in turn, support government policy proposals in exchange for pork and patronage (Amorim Neto, 2006; Pereira and Mueller, 2002; Alston and Mueller, 2006; Raile, Pereira and Power, 2011). If at all, the almighty president makes policy concessions (Raile et al., 2011) or delegates this task to certain ministers (Martinez-Gallardo, 2010), as if in permanent control of the legislative agenda formulation.

The conventional wisdom is that patronage and pork are sufficient to ensure coalition cooperation (Ames, 2001; Amorim Neto, 2006; Pereira and Mueller, 2002; Alston and Mueller, 2006; Raile, Pereira and Power, 2011). Hence, the proportionality in 
the distribution of cabinet portfolios to parties and the allocation and execution of legislators' (deputies and senators in Brazil) budgetary amendments are sufficient to understand the functioning of the coalition. Policy is a consequence of pork, as very cleverly spelled out by Alston and Mueller (2006). $0 r$, as said, policy concessions and delegation is an episodic and opportunistic strategy by presidents to appease dissatisfied coalition members or increase the likelihood of bill approval in Congress (Raile et al., 2011; Martinez-Gallardo, 2012).

Nonetheless, a different view argues that there is a shared legislative agenda among coalition members (Limongi and Figueiredo, 2008; 2009). Cooperation emerges from policy preferences and not pork or patronage alone. Such collaborative patterns of interaction between executive and legislative branches, as argued by Limongi and Figueiredo, should also be present within the executive branch. A corollary of their argument is that cabinet members from different parties in the coalition should work together if they agree on a shared legislative agenda. However, how is this conducted on a daily basis?

A first stepping-stone in rethinking the role of ministers in crafting the policy agenda is the work of Cecilia Martinez-Gallardo (2010). She argues that cabinet members affect policymaking as counselors to the president by sharing expertise, as negotiators with Congress, rallying their party's troops around the government's legislative agenda, and as implementers of the government's decisions (2010). Hence, ministers are not formulators of the agenda, as we argue. At best, they only provide some input, as counselors, but are not responsible for the content of legislation and public policies derived therefrom. Furthermore, she argues that cabinet formation (who composes the cabinet and how many), cabinet stability or its longevity, and the structure of the cabinet (its mechanisms of coordination) are central to understand policy content and quality. Indeed, she finds that smaller cabinets with clearly-defined jurisdictions and that last longer have a positive effect on public policy stability. However, this says nothing about how often and in which ways ministers actually formulate policy and collaborate in presidential systems.

In conclusion, the conventional view tells us that the institutional context influences the contours of the coalition. In presidential systems, presidential dominance over the legislative agenda should make cooperation among ministers heavily dependent upon the actions of the president. As we said, cooperation among ministers should be a rare event or only occur when the president demands it. Pork and patronage provide particularistic incentives to ensure individual loyalty, but should not unite ministers to collaborate. Ideological heterogeneity and a fragmented legislature should make cooperation more difficult. Our theory, which we spell out in detail below, claims that two types of role specialization within the cabinet lead to a shared gov- ernmental agenda. Further, such role specialization outweighs institutional pressures.

\section{A Coalitional Theory of Cabinet Cosponsorship}

Research in political science has provided a wealth of information concerning how presidents compose cabinet coalitions (Alemán and Calvo, 2010; Negretto, 2006; Amorim Neto, 2006; Cheibub et al., 2004; Martínez-Gallardo, 2010), and how cosponsorship networks of legislation influence legislative outcomes (Aleman, 2008; 2009; Aleman et al., 2009; Fowler, 2006; Tam Cho and Fowler, 2010; Kirkland, 2011). However, there has been no cross-pollination between these two branches of research. There is little discussion about how presidential choices over the characteristics of the cabinet influence the cosponsorship behaviors among members within the executive branch. Our theory brings these topics into careful analysis.

We make two main theoretical claims that we juxtapose with the conventional wisdom on how lawmaking occurs in presidential systems. First, we argue that presidents do not construct the government's agenda alone, imposing it on other coalition partners, buying them off through pork and patronage, or possibly making condescending policy concessions, as most analysts of presidential systems believe. We assert that policy proposals are formulated in the ministries and the presidency has a gatekeeping position, controlling the government's agenda negatively, by picking and choosing among proposals drawn up elsewhere.

Second, role specialization occurs between different ministries. For various reasons, some ministers have closer access to the president, are seen as more reliable by the president, who delegates more influence to them, allowing them to play a more active role in formulating the government's agenda. Ministers that are distant from the president will invest in increasing the legitimacy of their proposals so as to be encamped by the government. Ministers further from the inner circles of the president will need to build collective support for their proposals, as they occupy less important decision-making positions in the government. Hence, advancing one's pet projects will require different strategies by different ministers.

Still, the lawmaking role of ministers does not occur in an institutional vacuum. Crafting the government's agenda emerges within the complex interplay between top-down institutional forces and bottom-up ministerial forces acting in defining the government's agenda. Institutions set the rules concerning who can pick the teams - institutions give the president the power to construct the cabinet, define a coalition agreement, and set the government's budget. Hence, institutionally derived powers can influence coauthorship patterns, 
leading to a dominance of the president and his or her party over the formulation of the government's agenda, even if this is conditional upon the ideological characteristics of the cabinet. This is the essence of the conventional wisdom on lawmaking in presidential systems.

\section{Role Specialization 1: ministers as experts, president as gatekeeper}

The exact configuration of the cabinet coalition is less important for the drafting of policy than the contingent day-to-day challenges of governing. The president's resources to deal with complex policy challenges are paltry in comparison to the specialized skill residing in the ministries. Ministers seek to produce legitimate policy proposals that further the goals of their parties, while the president seeks to address a myriad of policy areas simultaneously, requiring the expertise of several ministers to do so effectively. The ministries possess technical skills and policy expertise, while the president wields control over the introduction of legislation in congress. Rather than policy segmentation or dominance of one actor over another, the construction of policy within the cabinet is far more interpenetrating and collegial than institutional arguments might suggest. ${ }^{2}$

To demonstrate how the formulation of legislation within ministries has changed over time, consider figure [number of ministers collaborating]. In figure [number of ministers collaborating] we plot the monthly legislative cosponsorship among ministers, in terms of the average number of ministers cosigning legislation each month (logged). The picture that emerges is a relatively consistent upward trend in the number of ministers involved in the legislative process across time in both the Cardoso and Lula administrations.

Ministers are key policymakers in presidential systems. We argue that it is within the institutional framework of ministries, where technocrats and area specialists dwell, that most policies are formulated. The presidential staff evaluates these policies, adjusts them according to the general government interest, coordinates among ministries, and submits proposals to Congress. The president and his/her close allies are not the sole or even main authors of most bills proposed by the executive branch. If so, it would need unlimited, almost supernatural, powers and resources. It is true that the organizational structure of the office of the president has evolved and grown in many countries, but not at the same rate as the production of law and policies in the executive branch. In fact, most area specialists in the government are not housed in the presidency, but in the ministries. It is within the realm of ministries that policy innovation is bred and these ideas transformed into normative instructions, decrees and bills.

We plot changes in the level of technocratic expertise versus partisan participation in the agenda over time by looking at the average ratio of technocratic ministers cosigning legislation across time. In figure [tech ministers], we plot the relative rate of technocratic ministers relative to partisan ministers cosponsoring legislation over time (logged) against those who are partisan. The picture that emerges is one in which inclusion of technical ministers increased under Cardoso, and continued for a time under Lula. However, in 2006 Lula appeared to begin delegating less to technical ministers and more to partisan ministers.

The president's staff members function as gatekeepers. They receives proposals from the different ministries, evaluate their content and assure they represent the interests of the government and that they are constitutional. Then the solicit input from other ministers when necessary, coordinate the interaction among ministries, and define the order in which bills will be submitted to Congress. The presidential staff may also completely block proposals. In fact, preventing the submission of a proposal to Congress is probably the most effective form for the president to control the government's legislative agenda. The presidency, unquestionably, has a key role in coordinating the formulation of the government's agenda, but not in authoring it.

\section{Role Specialization 2: core-class and peripheral ministers as concentric circles.}

Not all ministers and ministries are born equal. For instance, they vary in the size of their jurisdictions and budgets. Ministers may also be ideologically and personally close to the president, facilitating access and acceptance of their policy proposals. Ministers can also be co-partisans of the president or from parties that are ideologically close to the president's party.

These variations make a difference in how influential a minister is in affecting the government's agenda. We argue here that there are, at least, two overall types of ministers. Ministers with different standings in the cabinet should behave differently in advancing their policy proposals. Some are policy activists in the government and receive preferential treatment, including shielding from criticism and scandals (Dewan and Myatt, 2007). Other ministers, who might be more distant from the president, may be less prone to receive protection, and therefore more conservative and risk-averse in exposing themselves (Dewan and Myatt, 2007). In addition, junior ministers the president trusts may shadow potential rogue ministers (Thies, 2001). This implies differential treatment of cabinet members.

We refer to these two general types as core and peripheral ministers. Core-class ministers are those that because of partisan, ideological or personal reasons are close to the president. These ministers usually hold the most powerful ministries, which we define as the ones with broader jurisdictions or 
jurisdictions that are central to the government's overall agenda.

Core ministers have easy access to the president and should be common endorsers of the government's legislative initiatives. These ministers are usually from the same political party as the president and share the same electoral fate as the government. They cannot defect. So, their commitment to the government is above doubt. The president will protect such ministers until reputational costs to the entire government become unbearable.

Peripheral ministers, on the other hand, come from other parties in the coalition, and do not necessarily share the same ideological or policy preferences as the president. Peripheral ministers do not share the same electoral fate as the president, so defection is a real possibility. They also do not meet with the president often and should have less influence in the government's agenda. They usually hold peripheral ministries, with lower budgets and restricted jurisdictions that are not central to the government's overall agenda. Such people can easily turn into rogue ministers, whose proposals would require constant review and would raise more suspicions of their connectedness with the government's overall agenda (Martin and Vanberg, 2005). They might also be the ones more likely to have junior ministers in which the president trusts and that shadow the minister's decisions (Thies, 2001). Finally, these ministers would also be the least important ones when it comes to influencing policy, so they would be less protected by the president if involved in political scandals caused by policy failure or personal impropriety and would be the most likely to sit still, call less attention to themselves and pursue a modest legislative agenda (Dewan and Myatt, 2007).

We should expect different behaviors from ministers depending on the jurisdictions of their ministries and their parties. Core ministers should be influential participants in the government's coalition. Peripheral-class ministers should have a harder, uphill, battle to get their policy preferences across. As was said, they might be more scrutinized. We argue here that because of the differential standing of ministers, efforts to legitimize their individual proposals within the cabinet will vary by type of minister. Peripheral ministers might need greater networks of support within the cabinet to see their policy preferences advance in the executive branch. This would be a strategy to legitimize their proposals, by extending the collective reach and obtaining the support of a broader range of coalition members. Hence, we should expect the characteristics of ministers to affect which strategies they use to influence the government agenda.

Defining core- and peripheral ministers empirically is easier said than done. A first straightforward step is to differentiate ministers from the president's party and other members of the coalition. We then need to distinguish between the relevance of ministries. There is no consensus in the literature on how to rank ministries. We operationalize the idea of core and peripheral ministers using survey data. We use surveys with politicians to rank ministries because this technique condenses various different aspects of ministerial desirability, including jurisdiction and budgets. Federal deputies were asked to rank the most important ministries in the government in repeated surveys from 2011 to 2013 (FSB, 2013). We take the mean for each ministry in the entire period. Hence, our measure combines partisanship and ministry importance in defining our dichotomous variables core- and peripheral ministers. Core ministers are all those from the president's party, in spite of ministry, and those holding the following ministries: Planning, Justice, Finance, Casa Civil (Office of the President, headed by the chief of staff), Health, and Education. All other ministries will be considered in the peripheral class.

Based on this theory, we derive a few hypotheses to empirically test our arguments in contrast to the predominant, top-down view.

\section{Hypotheses:}

According to the institutional view, we should expect the president to have influence over the legislative agenda, rather than merely acting as a gatekeeper for legislation drafted by ministers. A low amount of interpenetration of ministerial agendas would be consistent with the view that the president dominates policy formulation. The president should construct a cabinet that approves the legislation of the president in return for patronage - the view of presidential legislative dominance. We should not expect the president to work with ministers to craft and refine legislation. The institutionally defined tools of the president to offer patronage - in particular the power over the budget - will be relatively dependent on the cooperative activities of the ministers.

Our main hypothesis is that ministers are important actors in defining the government's agenda and one should expect broad ministerial participation in authoring the agenda, especially from the peripheral ministers, who are not from the president's party and/or head second-tier ministries. Furthermore, peripheral ministers should engage in networking to advance their legislative initiatives by amassing support from several colleagues in the cabinet, involving them in the authorship of the proposal. Hence, policy authorship within the executive branch should be independent or suffer little influence of pork and patronage, and coauthorship should be a function of endogenous network features, such as the centrality of ministers.

Given that from an institutional view ministers from the president's party have the most incentive to coordinate on legislative issues, we expect that the most coauthorship will occur between ministers from the president's own party. Conversely, coauthorship will occur among peripheral ministers if they need to build support for their proposals. As such, we expect 
that role differentiation among ministers will manifest in less cross-class cosponsorship than would be expected by chance, and more within-class cosponsorship than would be expected by chance.

In figures [peripheral ministers], we show the increasing rate of peripheral ministerial participation in the agenda over time. We plot the average rate of peripheral participation in preparing the agenda by month (logged), plotting separate lines for each presidency.

\section{Data}

Our primary dataset records every legislative proposal authored by the executive branch from 1995 to 2010 in the Brazilian Congress, including proposals for ordinary laws, complementary laws ${ }^{3}$, constitutional amendments and provisional measures ${ }^{4}$, totaling 4,218 initiatives. It records the ministerial cosponsors of each legislative proposal, the party affiliation of those ministers, and the proposal's ultimate outcome. Bills are further classified as of substantive content, which indicates a proposal that ends in a law that has long-lasting impacts, and bills related to extraordinary budgetary credits, which have a defined time span, in that once the credit is approved and transferred to its destination, the law loses effectiveness. We supplement our primary dataset with ideology estimates from Power and Zucco (2009) and proportionality, affiliation, and support measures from Amorim Neto (2012)..$^{5}$

It should be clear here that we used only substantive legislative proposals, in opposition to budget requests, to measure network characteristics. The inclusion of extraordinary budget requests would exaggerate the centrality of the Ministry of Plan- ning, which is responsible for those requests. Given their special nature, these procedures are not truly comparable to bills on substantive policy issues.

In order to construct the ministerial and party networks, we simply split the data by the relevant time period (corresponding to cabinet period by month), and produced sociomatrices for each time point indicating cosponsorship on any piece of legislation within that period. Given M actors, a sociomatrix is an $M \times M$ dimension matrix with each cell indicating the number of cosponsorships between actor $i$ and $\mathrm{j}$, where $\mathrm{i} !=\mathrm{j}$. To do this in practice, we took the cross-product of an $L \times M$ matrix of the data, where $L$ indicates pieces of legislation and $M$ indicates the ministers. The cross-product here is the transpose of LXM multiplied by LXM.

Unfortunately, the data do not indicate who originated the bill and subsequent authors. They do not indicate who started a process, who reacted to it and in which order. They simply list who participated in authoring the legislative proposal. As such, the data are non-directional, meaning the ties do not distinguish between $A$ to $B$ and $B$ to $A$. Thus, we are left to examine simply whether two ministers cosponsored, not which one initiated the relationship.

\section{Descriptive Statistics of the Data}

We look at the entire coauthorship network aggregated across all cabinets to observe the descriptive characteristics of coauthorship in this context. We then evaluate these descriptive statistics in light of what the top-down theory may expect and what our (bottom-up) theory expects. Descriptive results are in Tables 1 and 2.

Table 1. Party Centrality Rankings Across Cabinets

\begin{tabular}{|c|c|c|c|c|c|}
\hline & Cabinets & Cabinets & Cabinets & Cabinets & Cabinets \\
\hline Rank & FHCI.1 & FHCI. 2 & FHCII.2 & FHCII.3 & FHCII.4 \\
\hline 1 & PSDB & SEM & SEM & PSDB & PFL \\
\hline 2 & MIL & PMDB & PT & SEM & PSDB \\
\hline 3 & PFL & PSDB & MIL & MIL & SEM \\
\hline 4 & PMDB & PFL & PFL & PFL & PMDB \\
\hline 5 & SEM & PT & PMDB & PPB & $\mathrm{PT}$ \\
\hline 1 & SEM & PMDB & PT & PV & PT \\
\hline 2 & PT & SEM & PMDB & PT & SEM \\
\hline 3 & PDT & PT & PR & $\mathrm{CN}$ & MIL \\
\hline 4 & PR & MIL & SEM & MIL & PMDB \\
\hline 5 & PV & PCdoB & $\mathrm{CN}$ & PCdoB & PDT \\
\hline 4 & PMDB & SEM & PDT & PR & SEM \\
\hline 5 & PR & PCdoB & PR & MIL & $\mathrm{PP}$ \\
\hline Rank & LULAII.5 & LULAII.6 & & & \\
\hline 1 & PMDB & PT & & & \\
\hline 2 & SEM & SEM & & & \\
\hline 3 & MIL & PMDB & & & \\
\hline 4 & PT & PSB & & & \\
\hline 5 & PFL & PCdo B & & & \\
\hline
\end{tabular}


Table 2. Minister Relationship Repetition

\begin{tabular}{|c|c|c|c|c|c|c|}
\hline & None & Formed & Dissolved & Repeated & Distance & Proportion \\
\hline Cabinets & $0 \rightarrow 0$ & $0 \rightarrow 1$ & $1 \rightarrow 0$ & $1 \rightarrow 1$ & Avg. Dist. & Repeated \\
\hline FHCI.1 $\rightarrow$ FHCI.2 & 775 & 104 & 8 & 59 & 224 & 0.35 \\
\hline FHCI.2 $\rightarrow$ FHCII.1 & 782 & 1 & 146 & 17 & 294 & 0.10 \\
\hline FHCII.1 $\rightarrow$ FHCII.2 & 638 & 290 & 6 & 12 & 592 & 0.04 \\
\hline FHCII.2 $\rightarrow$ FHCII. 3 & 637 & 7 & 228 & 74 & 452 & 0.24 \\
\hline FHCII. $3 \rightarrow$ FHCII. 4 & 814 & 51 & 30 & 51 & 162 & 0.39 \\
\hline FHCII.4 $\rightarrow$ LULAI.1 & 788 & 56 & 24 & 78 & 160 & 0.49 \\
\hline LULAI.1 $\rightarrow$ LULAI.2 & 751 & 61 & 40 & 94 & 202 & 0.48 \\
\hline LULAI. $2 \rightarrow$ LULAI.3 & 788 & 3 & 135 & 20 & 276 & 0.13 \\
\hline LULAI. $3 \rightarrow$ LULAI.4 & 922 & 1 & 23 & 0 & 48 & 0.00 \\
\hline LULAI.4 $\rightarrow$ LULAI. 5 & 836 & 109 & 1 & 0 & 220 & 0.00 \\
\hline LULAI. $5 \rightarrow$ LULAI. 6 & 789 & 48 & 29 & 80 & 154 & 0.51 \\
\hline LULAII.1 $\rightarrow$ LULAII.2 & 766 & 52 & 74 & 54 & 252 & 0.30 \\
\hline LULAII.2 $\rightarrow$ LULAII. 3 & 827 & 13 & 78 & 28 & 182 & 0.24 \\
\hline LULAII. $3 \rightarrow$ LULAII. 4 & 705 & 200 & 3 & 38 & 406 & 0.16 \\
\hline LULAII.4 $\rightarrow$ LULAII.5 & 702 & 6 & 189 & 49 & 390 & 0.20 \\
\hline LULAII.5 $\rightarrow$ LULAII. 6 & 790 & 101 & 18 & 37 & 238 & 0.24 \\
\hline DILMAI.1 $\rightarrow$ DILMAI.2 & 735 & 73 & 62 & 76 & 270 & 0.36 \\
\hline
\end{tabular}

We find that ministerial agendas are highly interpenetrating. In particular, over the time period our data cover, network density is $56 \%$, which is very similar to the density found in policy networks in Chile, and much higher than policy networks in Argentina (0.369) (Aleman and Calvo, 2013). In fact, our average social distance is similar to that found in cosponsorship networks in the US Congress (Fowler, 2006), suggesting that they have similar characteristics. To give a sense of the raw amounts of coauthorship, we found that the most active co-endorsing ministries are the Finance Ministry, Planning Ministry, Justice Ministry, Development, Industry and Foreign Trade Ministry, Labor Ministry and Social Security Ministry, whose ministers co-endorsed 1,405, 1,228, 761, 471, 400 and 384 pieces of legislation, respectively, over the study period. In examining ministerial rankings across cabinets over time, this group includes peripheral ministers and there is variability in which ministerial positions were most central in coauthorship networks.

\section{Final Comments}

Our results indicate that the patterns of collaboration within the coalition are quite common, contrary to initial expectations, and when it occurs, various members of the coalition participate. Furthermore, it is not the allocation of cabinet positions according to the strength of parties in Congress (patronage) or the distribution of supplementary credit requests (pork) that decreases shared authorship of the government's legislative agenda. Therefore, even if authorship is predominantly concentrated in just a few ministries led by appointees from the president's party (slightly over $50 \%$ for substantive bills) as Gaylord and Renno (2012) have shown, there is significant space and opportunity for the construction of a shared agenda among parties in the coalition. The process is oriented by a bottom- -up dynamics, in which presidents have less control over the construction of the government's agenda and ministers have more centrality than prior research indicates.

Unfortunately, the lack of comparative data does not allow us allow to say if levels of cosponsorship density and stability are high or low in Brazil. This is a task for future studies in countries where ministers also cosponsor bills, such as Argentina, Chile, Ecuador, Colombia, among others. Comparative studies will more appropriately contrast how variations in presidential power can affect collegial lawmaking within the executive. Hence, we provide here a first step in that direction.

Another factor we cannot control in our analysis is the importance of legislation. A party may hold a single ministry in the cabinet and propose a single bill during all of its tenure, but that might be enough to satisfy its constituency and policy agenda. Hence, it would not be the number of bills that matter, but their quality and importance. Unfortunately, our research is not designed to address this issue. More detailed case studies would be necessary to investigate the outliers in our analysis - those with a few bills or no bills - and what they really mean. However, without this first effort in data collection, these cases would not be identifiable and more nuanced research would be impossible. A future avenue of research would profit from investigating in more depth the parties and ministries that participate less often in the policymaking process and their motivations to continue in the government.

Future studies should also investigate the effect of density and stability in legislative outcomes. We find here that the density of cabinet cosponsorship networks is independent of patronage distribution and more closely associated with the ideological diversity of the cabinet. Hence, we can use measures 
of density as proxies to the level of interpenetration of ministerial agendas. A potential hypothesis for future testing is that the higher the levels of density among parties in the cabinet, the more successful the coalition will be in advancing its legislative agenda in Congress and avoiding legislative review. A common, shared agenda, represented by higher levels of density, should be more pleasing to the government's base of support in Congress, reducing amendment of the government's bills, expediting their processing, reducing obstruction and increasing the likelihood of approval. Still, we provide measures of network density, path length and relationship stability that can be used alongside measures of pork and patronage to more fully capture executive/legislative negotiations and how the coalition functions in Congress. ${ }^{6}$

Finally, in addition to the measure of density, one can also use the current data, especially measures of minister centrality, to rank ministers by their importance in cosponsoring the government's agenda. The importance of a portfolio is relevant to understand durability and reshuffles, even though the direction of the effect is not clear in the literature (Indridason and Kam, 2008; Huber and Martinez-Gallardo, 2008). Hence, the literature on cabinet duration could benefit from objective measures of ministerial ranking according to a well-defined criterion such as their participation in constructing the government's agenda. In addition, centrality could also be used to calibrate measures of cabinet proportionality. A common criticism of Amorim Neto's measure is that it ignores the relevance of the portfolio. By incorporating portfolio and weighting the distribution of ministries considering their centrality in prior governments, one could improve the already widely used measures of proportionality in portfolio allocation.

In this paper we investigated aspects of the coalition that had never been analyzed before. We found interesting characteristics of how coalitions function as networks and came to a few counterintuitive results about how coalition members collaborate within the executive branch in Brazil. We found evidence of shared responsibility among different parties in the coalition, providing some supportive evidence to Limongi and Figueiredo's claims. Even though this tends to occur less often than single authorship (Gaylord and Renno, 2012), which is also expected under strong presidential system as Brazil, we show that cosponsorship is quite frequent.

Still, our theory of ministerial authorship of the government's legislative agenda, including differential strategies by core- and peripheral ministers, has held up on its first test using a specifically designed dataset for this purpose. This theory sheds new light on how cabinet members interact in jointly constructing the government's agenda and how the presidency plays a gatekeeping role instead of an agenda-setting one in this process. We point to the possibility that presidents may not be as powerful, omnipresent and omniscient as conventional wisdom leads one to believe. Instead, it is the everyday negotiation among those in the executive branch that defines the policy content of government bills.

\section{Figures}

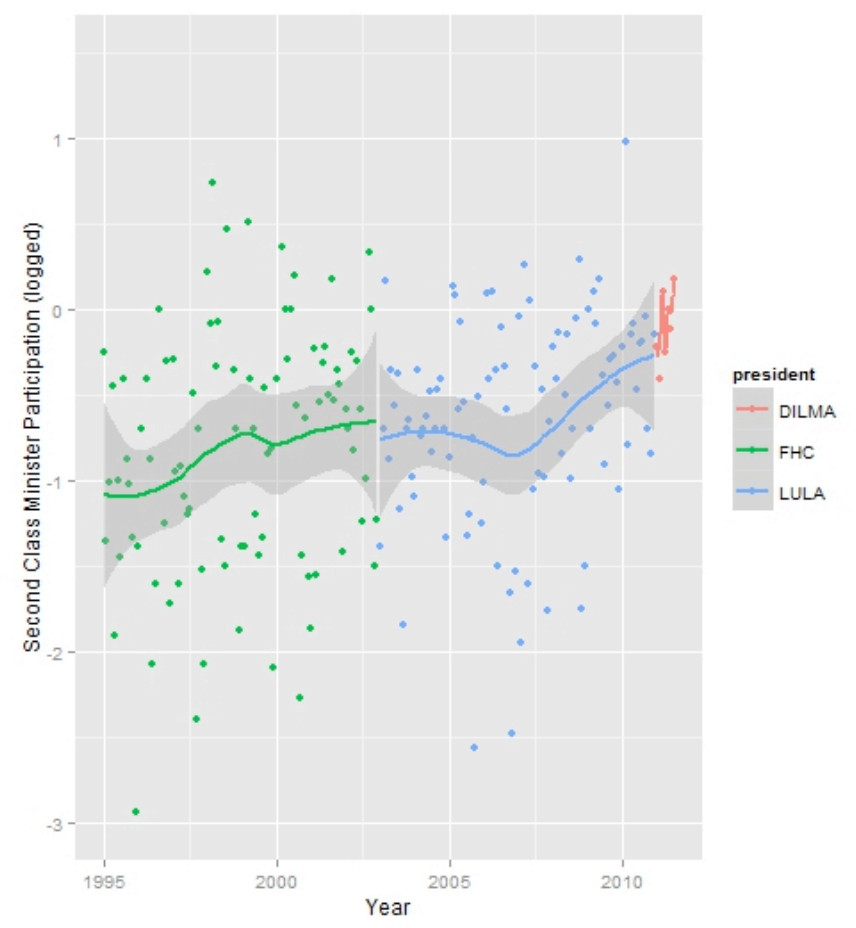


Figure 1. Lula's First and Second Terms
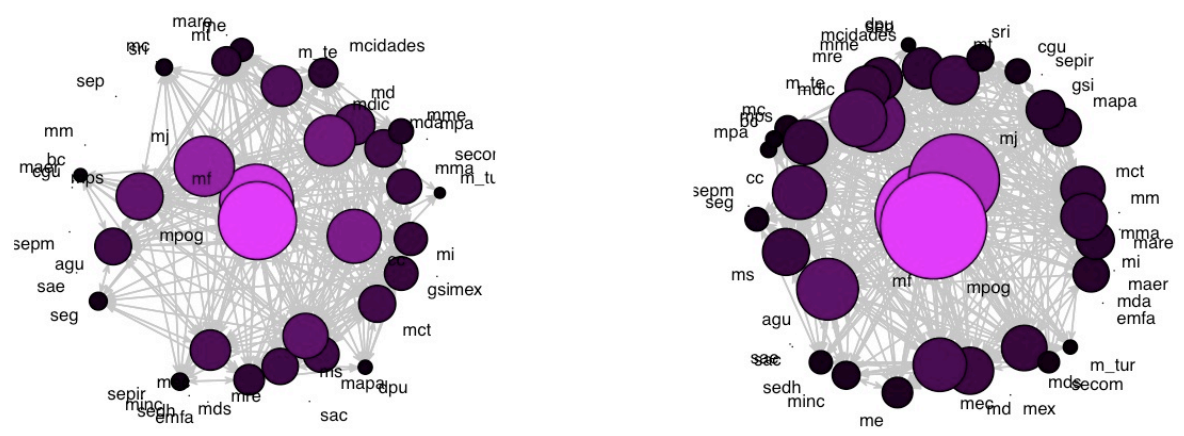

Figure 2. Cardoso's First and Second Terms
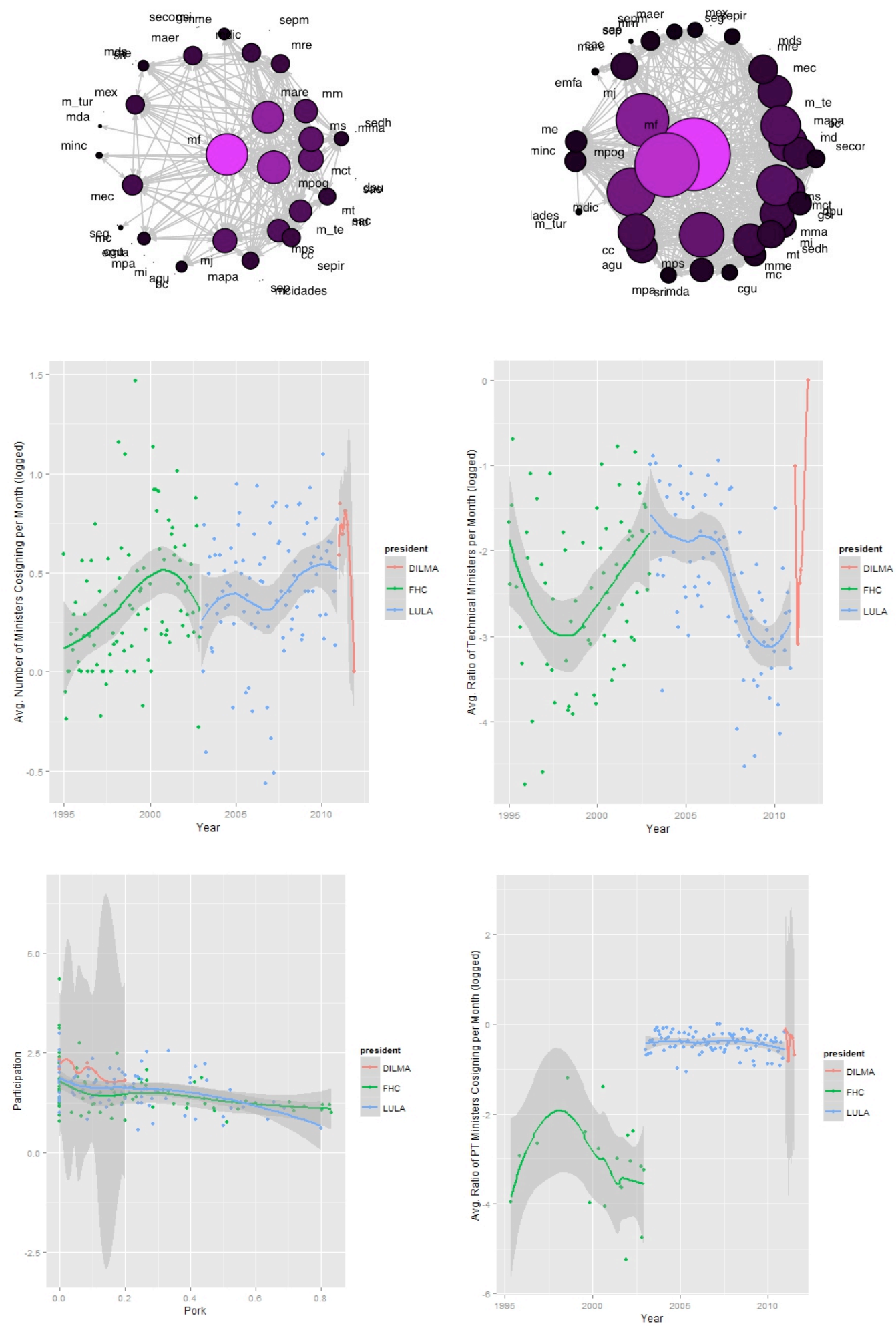


\section{References}

ALEMÁN, Eduardo. 2008. "Policy Positions in the Chilean Senate: An Analysis of Coauthorship and Roll Call Data," Brazilian Political Science Review, 2(2): 74-92.

ALEMÁN, Eduardo, CALV0, Ernesto, JONES, Mark P., and KAPLAN, Noah. 2009. “Comparing Cosponsorship and Roll-Call Ideal Points," Legislative Studies Quarterly, 34(1):87-116.

ALEMÁN, Eduardo and CALV0, Ernesto. 2010. “Unified Government, Bill Approval, and the Legislative Weight of the President," Comparative Political Studies, 43(4): 511-534.

ALEMÁN, Eduardo and CALV0, Ernesto. 2013. "Explaining Policy Ties: A Network Analysis of Bill Initiation Data." Political Studies, 61(2): 356-377.

ALEMÁN, Eduardo and SAIEGH, Sebastián M. 2007. “Legislative Preferences, Political Parties and Coalition Unity in Chile," Comparative Politics, 39(3): 253-272.

ALSTON, Lee and MUELLER, Bernardo (2006) "Pork for Policy: Executive and Legislative Exchange in Brazil". Journal of Law, Economics and Organization 22 (1): 87-114.

AMES, B. (2001). The Deadlock of Democracy in Brazil: Interests, Identities, and Institutions in Comparative Politics. Ann Arbor: University of Michigan Press.

AMORIM NETO, Octavio. 2002. "Presidential cabinets, electoral cycles, and coalition discipline in Brazil." In Legislative politics in Latin America, edited by Scott Morgenstern and Benito Nacif. Cambridge, UK: Cambridge University Press.

AMORIM NETO, Octavio. 2006. “The Presidential Calculus: Executive Policy Making and Cabinet Formation in the Americas." Comparative Political Studies, 39:4, 415-440.

AMORIM NETO, Octavio. 2012. “El Moderno Sistema de Gobierno Presidencial Brasileño." In Presidencialismo y Parlamentarismo: América Latina y Europa Meridional, edited by Jorge Lanzaro. Madrid, Spain: CEPC.

AMORIM NET0, Octavio, Gary Cox and Matthew D. McCubbins 2003. "Agenda Power in Brazil's Câmara dos Deputados 1989-1998." World Politics 55.

CAMERLO, Marcelo. 2013 "Gabinetes de partido único y democracias presidenciales. Indagaciones a partir del caso argentino." America Latina Hoy 64, 119-142.

CARRERAS, Miguel. 2013. "Presidentes outsiders y ministros neófitos: un análisis a través del ejemplo de Fujimori." America Latina Hoy 64, 95-118.

CHASQUETTI, Daniel, BUQUET, Daniel And CARDARELLO, Antonio. 2013. “La designación de gabinetes en Uruguay: estrategia legislativa, jerarquía de los ministerios y afiliación partidaria de los ministros." America Latina Hoy 64, 15-40.

CHEIBUB, J. A. 2007. Presidentialism, parliamentarism, and democracy. Cambridge Univ Press.

CHEIBUB, J. A and F. Limongi. 2002. “Democratic institutions and regime survival: parliamentary and presidential democracies reconsidered." Annual Review of Political Science 5(1):151-179.

D'AVILA, Mireya, OLIVARES LAVADOS, Alejandro, and AVENDAÑ0, Octavio. 2013. “Los gabinetes de la Concertación en Chile (1990-2010)." America Latina Hoy 64, 67-94.

DESMARAIS, Bruce A., and Cranmer, Skyler J.. 2010. Analyzing longitudinal networks: the temporal exponential random graph model. In Midwest Political Science Association Annual Meeting, April 22, Chicago, IL.

DEWAN, Turan, and MYATT, David P. 2007. "Scandal, Protection, and Recovery in the Cabinet." American Political Science Review, 101(1), 63-67.

FAUST, Katherine, and SKVORETZ, John. 2002. "Comparing networks across space and time, size and species." Sociological Methodology. 32:267-99.

FRANKEL, Philip H. 1980. "South Africa: The Politics of Police Control." Comparative Politics 12(4).

FIGUEIREDO, Argelina, and LIMONGI, Fernando. 1999. Executivo e Legislativo na nova ordem constitucional. Rio de Janeiro: Editora FGV.

FIGUEIRED0, Argelina, and LIMONGI, Fernando. 2002. "Incentivos eleitorais, partidos e política orçamentária." Dados, 45(2), 303-344.

FIGUEIRED0, Argelina, and LIMONGI, Fernando. 2008. Política Orçamentária no Presidencialismo de Coalizão. Editora FGV: Rio de Janeiro, Brasil.

FIGUEIREDO, Argelina, and LIMONGI, Fernando. 2009. “Poder de Agenda e Políticas Substantivas." In: Magna Inácio and Lucio Renno (eds.) Legislativo brasileiro em perspectiva comparada. Editora UFMG: Belo Horizonte, Brasil.

FSB CONSULTING. 2013. "Serie Ministros Mais Importantes." Brasília, DF, Brazil. Received by email on August 28, 2013.

GAYLORD, Sylvia and RENNO, Lucio. 2012. "The Role of the Cabinet in Legislative Production in Brazil." Delivered at the 22nd IPSA World Congress of Political Science, Madrid, Spain, July 8-12.

HACKER, Jacob S. and PIERSON, Paul. 2012. "Presidents and the Political Economy: The Coalitional Foundations of Presidential Power." Presidential Studies Quarterly 42(1).

HUBER, John and MARTINEZ-GALLARD0, Cecilia. 2008. “Replacing Cabinet Ministers: Patterns of Ministerial Stability in Parliamentary Democracies." American Political Science Review 102: 169-180.

INACI0, Magna. 2013. “Escogiendo ministros y formando políticos: los partidos en gabinetes multipartidistas." America Latina Hoy 64, 41-66.

INDRADISON, I. and KAM, C. 2008. “Cabinet Shuffles and Ministerial Drift." British Journal of Political Science 38: 621-656. 
Introduction to social network methods. 2005. URL: http://faculty.ucr.edu/ hanneman/

LAVER, Michael, and SHEPSLE, Kenneth. 1994. Cabinet Ministers and Parliamentary Government. Cambridge, UK: Cambridge University Press.

LAVER, Michael and SHEPSLE, Kenneth A.. 1996. Making and Breaking Governments: Cabinets and Legislatures in Parliamentary Democracies. Cambridge: Cambridge University Press.

MAINWARING, S. 1993. "Presidentialism, Multipartism, and Democracy The Difficult Combination." Comparative political studies, 26(2), 198-228.

MARTIN, L. W., and VANBERG, G. 2004. "Policing the bargain: Coalition government and parliamentary scrutiny." American Journal of Political Science, 48(1), 13-27.

MARTINEZ-GALLARDO, Cecilia. 2010. "Inside the Cabinet: The Influence of Ministers in the Policymaking Process." In Carlos Scartascini, Ernesto Stein and Mariano Tomassi (eds.), How Democracy Works. Political Institutions and Arenas in Latin American Policymaking. Cambridge, MA: Inter-American Development Bank.

MARTINEZ-GALLARDO, Cecilia. 2012. "Out of the Cabinet: What Drives Defections from Government in Presidential Systems." Comparative Political Studies 45(1).

NEGRETT0, Gabriel L. 2004. "Government Capacities and Policy Making by Decree in Latin America The Cases of Brazil and Argentina." Comparative Political Studies, 37(5), 531-562.

NEGRETTO, Gabriel L. 2006. “Minority presidents and democratic performance in Latin America." Latin American Politics and Society, 48(3), 63-92.

PAPKE, Leslie and WOOLDRIDGE, Jeffrey M. 2008. “Panel data methods for fractional response variables with an applications to test pass rates". Journal of Econometrics 145.

PEREIRA, Carlos, POWER, Timothy J., and RENNO, Lucio. 2005. “Under what conditions do presidents resort to decree power? Theory and evidence from the Brazilian case." Journal of Politics, 67(1), 178-200.

PEREIRA, Carlos, POWER, Timothy J., and RENNO, Lucio. 2008. "Agenda power, executive decree authority, and the mixed results of reform in the Brazilian congress." Legislative Studies Quarterly, 33(1), 5-33.

PEREIRA, Carlos and MUELLER, Bernardo. 2002. “Comportamento Estratégico em Presidencialismo de Coalizão: As Relações entre Executivo e Legislativo na Elaboração do Orçamento Brasileiro." Dados, 45(2), 265-301.

POWER, Timothy and ZUCCO, Cesar. 2009. "Estimating Ideology of Brazilian Legislative Parties, 1990-2005." Latin American Research Review 44(1).

RAILE, E. D., PEREIRA, C., \& POWER, T. J. (2011). The executive toolbox: building legislative support in a multiparty presidential regime. Political Research Quarterly, 64(2), 323-334.

SAIEGH, S. M. (2010). "Active players or rubber stamps? An evaluation of the policymaking role of Latin American legislatures." In Carlos Scartascini, Ernesto Stein and Mariano Tomassi (eds.), How Democracy Works. Political Institutions and Arenas in Latin American Policymaking. Cambridge, MA: Inter-American Development Bank.

SC0T, John. 2000. Social Networks Analysis: A Handbook. Sage Publications.

STROM, K. (1990). A behavioral theory of competitive political parties. American journal of political science, 565598.

THIES, M. F. (2001). Keeping tabs on partners: The logic of delegation in coalition governments. American Journal of Political Science, 580-598.

\section{Notes}

* Lucio R. Renno is Associate (Adjunto) Professor of the Political Science Institute, University of Brasilia. He received his Ph.D. in Political Science from the University of Pittsburgh in 2004. His publications on legislative politics, voting behavior and public opinion have appeared in Comparative Political Studies, American Journal of Political Science, Legislative Studies Quarterly, Latin American Politics and Society, Journal of Politics, Journal of Latin American Studies, Journal of Legislative Studies, Electoral Studies, Revista Brasileira de Ciências Sociais, Novos Estudos Cebrap, Dados - Revista de Ciencias Sociais, and Opinião Pública. He is co-editor of Reforma Politica: Lições da História Recente, Editora da FGV, Rio de Janeiro, 2006, Reforma Política em Questão, Editora da UnB, Brasília, 2008 and Legislativo Brasileiro em Perspectiva Comparada, Editora da UFMG, Belo Horizonte, 2009 and co-author of Legitimidade e Qualidade da Democracia: Uma Visão da Cidadania, Editora Intermeios, São Paulo, 2011 and Responsividade Democrática no Brasil de Lula e na Argentina, Paco Editorial, São Paulo, 2015.

* Postdoctoral Fellow. Stefan's research agenda focuses on both political network analysis and the application of network-analytic techniques to data problems, among other interests. He is currently a Postdoctoral Fellow at the Lazer Lab at Northeastern University and a Visiting Fellow at Harvard's IQSS.

1 Constitutions in many countries such as Brazil, Argentina, Mexico, Uruguay, Chile, Colombia, among others, specify that ministers ratify official documents under their jurisdiction, creating the institutional basis for cabinet members' bill authorship. This indicates that the theory we develop may apply to many other cases.

2 In parliamentary systems, cabinet members are frequently seen as lawmakers (Thies, 2001; Martin and Vanberg, 2004; Dewan and Myatt, 2007). In presidential systems, probably due to the inordinate influence of the study of the United States, where cabinet members matter little, not much is known about the role of ministers.

3 Complementary laws (leis complemntares) are enabling laws of constitutional provisions, with higher status that ordinary laws. 
4 Provisional measures (medidas provisórias) are presidential decrees that take immediate effect with status of ordinary law, but then are subject to congressional approval/rejection/amendment, under a priority regime. They are limited to "relevant and urgent" matters and are an important mechanism for governability in Brazil's multiparty presidential system, but one that tempts abuse.

5 The 1988 Brazilian Constitution establishes that ministers must ratify official government documents, thus granting them the legal power author legislative initiatives within the executive branch. What does the ratification mean regarding the input and investment of ministers? In-depth interviews with staff in the presidency and various ministries in Brazil indicate that the ratification or endorsement of legislative proposals mean various forms of minister participation in the formulation of a legislative initiative, as was argued in the introduction. At the minimum, endorsement requires some interaction between ministers and ministerial staff; ministries invest time and other scarce resources. In addition, this is not just the best, but the only available indicator of authorship within the executive branch.

6 Our multidimensional approach to cooperation on policy formulation can be used in future studies as independent variables to explain the government's legislative success and of executive/legislative relations. Hence, our study also contributes methodologically to the study of coalitions by applying a new analytical framework and generating new indicators of coalition interconnectedness, a competing measure of coalition management based on policy authorship and not pork or patronage. These new measures based on the network analysis framework of the policymaking characteristics of cabinets can be applied side-by-side with the already existing measures of proportionality in the distribution of cabinet slots, which tends to capture patronage. 